\title{
The Courage of the Commedia
}

"Or va, ch'un sol volere è d'ambedue: tu duca, tu segnore e tu maestro". Così li dissi; e poi che mosso fue, intrai per lo cammino alto e silvestro.

(Inf. II.139-42) ${ }^{1}$

1. Paul Tillich, The Courage To Be, and species of ontological anxiety: the anxiety of death and fate - the anxiety of guilt and condemnation - the anxiety of meaninglessness. 2. A further distinction: the courage to be as part and the courage to be as oneself. 3. Dante and the courage to be as part (civitas, imperium and ecclesia). 4. Dante and the courage to be as oneself: the moment of acknowledgement (Inferno), the moment of alignment (Purgatorio), and the moment of actualization (Paradiso). 5. Conclusion: the courage of the pilgrim and the courage of the poet.

In his book The Courage To Be, Paul Tillich identifies three forms of ontological anxiety, of the kind of anxiety which, transcending the merely circumstantial, rises up from the depths to constitute the dominant mood of existence. First comes the kind pertaining to being - by which we mean this or that instance of specifically human being - as it contemplates nonbeing as its polar counterpart. This, Tillich calls the anxiety of fate and of death, an order of anxiety engendered by the rhythm of unpredictability in human experience and confirmed in its power to terrify by the prospect sooner rather than later of ceasing to be. ${ }^{2}$ Courage as the courage to be

1 "Now on, for a single will is in us both; you are my leader, you my master and my teacher." So I said to him, and when he moved on, I entered along the deep and savage way. What follows is the revised version of a lecture by the same title delivered in University College London on 25 April, 2007 as the twelfth Alan Marre Maccabaeans Centenary Lecture in the Humanities. I am grateful to René Weiss, Professor of English in University College London and (at that time) Chair of the Maccabaeans Lectureship Committee for his kindness to me on that occasion.

2 Paul Tillich, The Courage To Be (Glasgow: Collins, 1977; originally 1952), pp. $52-$ 53: 'The threat of non-being to man's ontic self-affirmation is absolute in the threat of death, relative in the threat of fate. But the relative threat is a threat only because in its background stands the absolute threat. Fate would not produce inescapable anxiety without death behind it. And death stands behind fate and its contingencies not only 
enters into this situation as that whereby the individual seeks even so to affirm self in the fundamental intelligibility and thus in the fundamental security of self, thus offsetting as far as may be those forces operative both from within and from beyond making by way of fear for a tearing down, as distinct from a building up, of historical selfhood. This, Tillich notes, was what Plato had in mind when in attempting to identify the dynamic element in human experience, he settled upon its thymotic or spirited component $(\theta \nu \mu \rho \varsigma)$ as dwelling somewhere between reason and desire and quickening the whole in respect of its proper finality. ${ }^{3}$ It was what Aristotle had in mind when it came to the notion of bravery as a matter, not merely of military, but of moral concern, of a man's readiness 'to endure or fear the right things, for the right purpose, in the right manner, and at the right time', all this making for a nobility of spirit. ${ }^{4}$ And it was what the Stoics

in the last moment when one is thrown out of existence but in every moment within existence. Non-being is omnipresent and produces anxiety even where an immediate threat of death is absent. It stands behind the experience that we are driven, together with everything else, from the past toward the future without a moment of time which does not vanish immediately. It stands behind the insecurity and homelessness of our social and individual existence. It stands behind the attacks on our power of being in body and soul by weakness, disease and accidents. In all these fate actualizes itself, and through them the anxiety of non-being takes hold of us. We try to transform the anxiety into fear and to meet courageously the objects in which the threat is embodied. We succeed partly, but somehow we are aware of the fact that it is not these objects with which we struggle that produce the anxiety but the human situation as such. Out of this the question arises: Is there a courage to be, a courage to affirm oneself in spite of the threat against man's ontic self-affirmation?' Dante on the death as the far limit of significant activity, Purg. XXXIII.54: 'del viver ch'è un correr a la morte'.

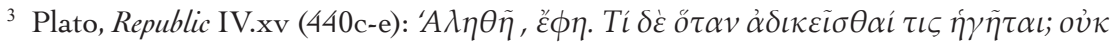

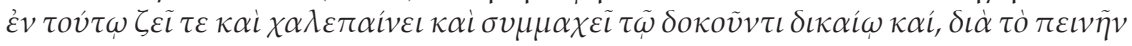

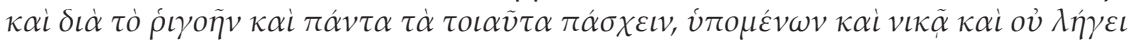

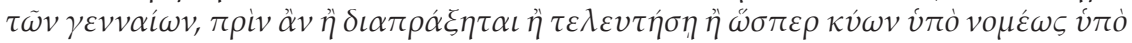

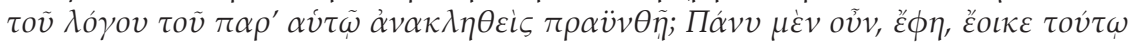

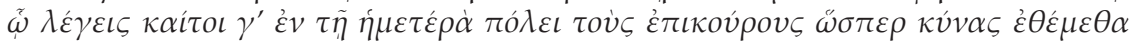

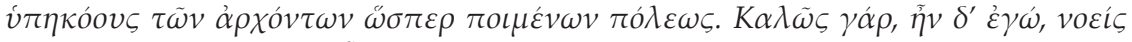

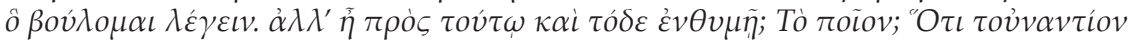

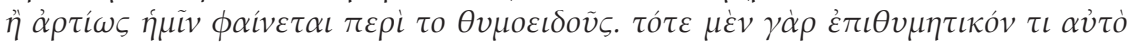

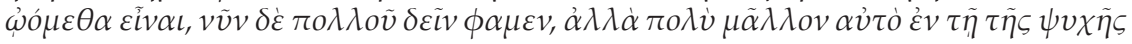

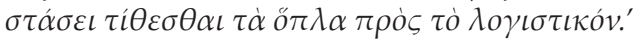

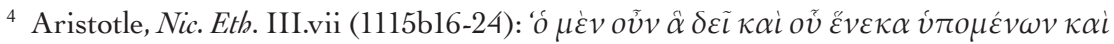

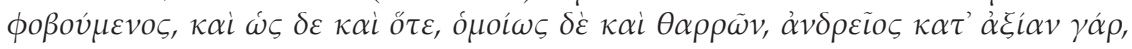

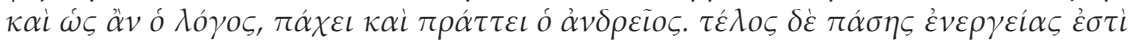

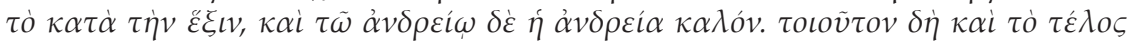

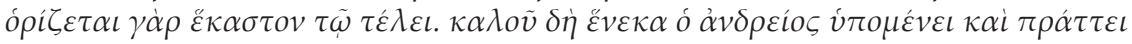
$\tau \dot{\alpha} \kappa \alpha \tau \dot{\alpha} \tau \dot{\eta} v \dot{\alpha} v \delta \rho \varepsilon i \alpha v$.' Thomas, ad loc. (III.xv, n. 6): 'Dicit ergo primo, quod ille qui sustinet quae oportet sustinere et fugit per timorem ea quae oportet vitare, et facit hoc eius gratia cuius oportet et eo modo quo oportet et quando oportet, vocatur fortis. Qui 
had in mind when, sensitive to the challenge mounted by fate and death to the integrity and intelligibility of this or that act of specifically human being, they looked to the kind of self-sufficiency whereby the individual remains equal to the vicissitudes of the world as ranged over against him. ${ }^{5}$ Courage thus understood, clearly, falls well short of the kind of courage whereby the guilt of estrangement is taken into self as the condition of its liquidation, Stoic courage in this sense being a matter, less of recognition than of resolve, of standing in the $\lambda$ ógos as a reply to the threat to existence everywhere mounted by existence. But for all that, it is ontological in kind, attuned to the problematics, not merely of right doing, but of right being as an object of concern.

But if the dominant species of anxiety in the ancient world is the anxiety of fate and of death, this, though never eclipsed as the deepest and most insistent form of ontological apprehension in human experience, is overlaid in successive periods of western sensibility by the anxiety of guilt and condemnation characteristic of the high Middle Ages and the early modern world, and by the anxiety of meaninglessness characteristic

etiam similiter audet quae oportet, et cuius gratia et cetera. Et huius rationem assignat dicens quod quia fortis et virtuosus patitur per timorem et operatur per audaciam, secundum quod dignum est et secundum quod recta ratio dictat. Omnis enim virtus moralis est secundum rationem rectam, ut supra habitum est.'

${ }^{5}$ The Courage To Be cit. (note 2 above), pp. 23-24: 'The Stoic courage is, in the ontological as well as the moral sense, "courage to be". It is based on the control of reason in man. But reason is not in either the old or the new Stoic what it is in contemporary terminology. Reason, in the Stoic sense, is not the power of "reasoning", of arguing on the basis of experience and with the tools of ordinary or mathematical logic. Reason for the Stoics is the Logos, the meaningful structure of reality as a whole and of the human mind in particular. "If there is", says Seneca, "no other attribute which belongs to man as man except reason, then reason will be his one good, worth all the rest put together". This means that reason is man's true or essential nature, in comparison with which everything else is accidental. The courage to be is the courage to affirm one's own reasonable nature over against what is accidental in us. It is obvious that reason in this sense points to the person in his centre and includes all mental functions. Reasoning as a limited cognitive function, detached from the personal centre, never could create courage. One cannot remove anxiety by arguing it away. This is not a recent psychoanalytical discovery; the Stoics, when glorifying reason, knew it as well. They knew that anxiety can be overcome only through the power of universal reason which prevails in the wise man over desires and fears. Stoic courage presupposes the surrender of the personal centre to the Logos of being; it is participation in the divine power of reason, transcending the realm of passions and anxieties. The courage to be is the courage to affirm our own rational nature, in spite of everything in us that conflicts with its union with the rational nature of beingitself.' Cicero (in the course of his reconstruction of the moral systems of antiquity), De fin. III.ix.31: 'Circumscriptis igitur iis sententiis quas posui, et iis si quae similes earum sunt, relinquitur ut summum bonum sit vivere scientiam adhibentem earum rerum quae natura eveniant, seligentem quae secundum naturam et quae contra naturam sint reicientem, id est convenienter congruenterque naturae vivere', etc. 
of the modern world. The anxiety of guilt and condemnation is there whenever the individual sensitive to the part he himself has to play in the working out of his historical and eschatological destiny is at the same time possessed by a sense of his perversity, of his both willing and not willing at one and the same time. Impressed to the point of oppressed by his unrighteousness, he stands forever indicted in the forum of conscience and prey to despair. ${ }^{6}$ Courage as the courage to be enters into this situation as that whereby, embarking on the way of sorrowing and of repentance, the individual delivers himself to grace either as a principle of additional formality (Aquinas) or else as a principle of acceptability in the midst of unacceptibility (Luther), either way the burden of guilt and condemnation finding relief in a movement of faith as the beginning of new life. The anxiety of meaninglessness, by contrast, is there whenever the individual concerned on the plane of self-intelligibility feels unable to discern within

${ }^{6}$ The Courage To Be cit. (note 2 above), pp. 58-59: 'Non-being threatens from a third side: it threatens man's moral self-affirmation. Man's being, ontic as well as spiritual, is not only given to him but also demanded of him. He is responsible for it; literally, he is required to answer, if he is asked, what he has made of himself. He who asks him is his judge, namely he himself, who, at the same time, stands against him. This situation produces the anxiety which in relative terms is the anxiety of guilt; in absolute terms, the anxiety of self-rejection or condemnation. Man is essentially "finite freedom"; freedom not in the sense of indeterminacy but in the sense of being able to determine himself through decisions in the centre of his being. Man, as finite freedom, is free within the contingencies of his finitude. But within these limits he is asked to make of himself what he is supposed to become, to fulfil his destiny. In every act of moral self-affirmation man contributes to the fulfilment of his destiny, to the actualization of what he potentially is. It is the task of ethics to describe the nature of this fulfilment, in philosophical or theological terms. But however the norm is formulated man has the power of acting against it, of contradicting his essential being, of losing his destiny. And under the conditions of man's estrangement from himself this is an actuality. Even in what he considers his best deed non-being is present and prevents it from being perfect. A profound ambiguity between good and evil permeates everything he does, because it permeates his personal being as such ... The awareness of this ambiguity is the feeling of guilt. The judge who is oneself and who stands against oneself, he who "knows with" (conscience) everything we do and are, gives a negative judgment, experienced by us as guilt.' Thomas on despair as sin, ST IIa IIae.20.1 resp.: 'secundum philosophum, in VI Ethic., id quod est in intellectu affirmatio vel negatio est in appetitu prosecutio et fuga, et quod est in intellectu verum vel falsum est in appetitu bonum et malum. Et ideo omnis motus appetitivus conformiter se habens intellectui vero, est secundum se bonus, omnis autem motus appetitivus conformiter se habens intellectui falso, est secundum se malus et peccatum. Circa Deum autem vera existimatio intellectus est quod ex ipso provenit hominum salus, et venia peccatoribus datur; secundum illud Ezech. XVIII, nolo mortem peccatoris, sed ut convertatur et vivat. Falsa autem opinio est quod peccatori poenitenti veniam deneget, vel quod peccatores ad se non convertat per gratiam iustificantem. Et ideo sicut motus spei, qui conformiter se habet ad existimationem veram, est laudabilis et virtuosus; ita oppositus motus desperationis, qui se habet conformiter existimationi falsae de Deo, est vitiosus et peccatum.' 
him the still centre of that existence, this too serving both to sustain and to be sustained by a movement of despair. ${ }^{7}$ Courage as the courage to be enters now as that whereby the acknowledgement of meaninglessness comes in itself to constitute a meaningful act, at which point being, despite every inkling to the contrary, triumphs over non-being as a principle of self-understanding. ${ }^{8}$ Here too, therefore, in the context of anxiety as the anxiety of meaninglessness, courage as the courage to be breaks through to neutralize everything within the economy of personality making for resignation as a response to the agony of existence.

2. Now, however, the argument is subject to further inflexion, for the idea of courage thus understood - as a matter of the courage to be in respect of the anxiety of fate and death, of guilt and condemnation, and of meaninglessness - admits of a further distinction between the courage to be as part and the courage to be as oneself. By the expression 'courage to be as part', Tillich has in mind the kind of courage whereby the individual alert to the problematics of his existence under the conditions of time and space seeks to assuage his anxiety by way of allegiance to the structures of collective and of institutional consciousness by which he is sustained and reassured in respect of the

7 ibid., pp. 54-55: 'The anxiety of meaninglessness is anxiety about the loss of an ultimate concern, of a meaning which gives meaning to all meanings. This anxiety is aroused by the loss of a spiritual centre, of an answer, however symbolic and indirect, to the question of the meaning of existence.' Further on the place of systematic doubt in the spiritual life, and on the shading off of systematic doubt into existential despair, pp. 55-56: 'Emptiness and loss of meaning are expressions of the threat of non-being to the spiritual life. This threat is implied in man's finitude and actualized by man's estrangement. It can be described in terms of doubt, its creative and its destructive function in man's spiritual life. Man is able to ask because he is separated from, while participating in, what he is asking about. In every question an element of doubt, the awareness of not having, is implied. In systematic questioning systematic doubt is effective, e.g. of the Cartesian type. This element of doubt is a condition of all spiritual life. The threat to spiritual life is not doubt as an element but total doubt. If awareness of not having has swallowed up the awareness of having, doubt has ceased to be methodological asking and has become existential despair.'

8 ibid., p. 171: 'The faith which makes the courage of despair possible is the acceptance of the power of being, even in the grip of non-being. Even in the despair about meaning being affirms itself through us. The act of accepting meaninglessness is itself a meaningful act. It is an act of faith. We have seen that he who has the courage to affirm his being in spite of fate and guilt has not removed them. He remains threatened and hit by them. But he accepts his acceptance by the power of being-itself in which he participates and which gives him the courage to take the anxieties of fate and guilt upon himself. The same is true of doubt and meaninglessness. The faith which creates the courage to take them into itself has no special content. It is simply faith, undirected, absolute. It is undefinable, since everything defined is dissolved by doubt and meaninglessness.' 
otherwise impossible loneliness of his presence in the world. ${ }^{9}$ In fact, Tillich is careful in the course of his argument to distinguish between what he sees as primitive and as developed forms of the courage to be as part. Primitive versions - recrudescences of which, he thinks, are discernible in certain kinds of modern totalitarianism - are primitive in the degree to which the collective solution is espoused as a matter of course, there being as yet no developed sense of the problematics of selfhood..$^{10}$ Advanced manifestations of this same phenomenon, however, are advanced in the degree to which, albeit within the context of collective consciousness as the means of self-actualization, there is even so some doubt as to the power of that consciousness fully to resolve the sensation of personal anxiety, an element of misgiving thus ruling out unqualified submergence of the private in the collective - a situation discernible, Tillich thinks, in the bourgeois conformism of the modern world. Even so, the fundamental pattern is the same, the courage to be as part commending itself as a way of overcoming the sensation of ontological anxiety and thus of drawing its sting. True, without the courage to be as oneself as its innermost principle, Tillich says, ${ }^{11}$ the courage to be as part can never be equal to the problem it seeks to address, for the problem it seeks to address can only ever be resolved by a coming home of self to the deep reasons of self; but in the degree to which the soul in its far-offness is strengthened by the institutions and ideologies which it embraces and by which it is in turn embraced

${ }^{9}$ ibid., p. 93: 'The courage to be as part is the courage to affirm one's own being by participation. One participates in the world to which one belongs and from which one is at the same time separated. But participating in the world becomes real through participation in those sections of it which constitute one's own life. The world as a whole is potential, not actual. Those sections are actual with which one is partially identical. The more self-relatedness a being has the more it is able, according to the polar structure of reality, to participate. Man as the completely centred being or as a person can participate in everything, but he participates through that section of the world which makes him a person. Only in the continuous encounter with other persons does the person become and remain a person. The place of this encounter is the community.'

${ }^{10}$ In the context of primitive collectivism, the individual 'affirms himself through the group in which he participates. The potential anxiety of losing himself is not actualized, because the identification with the group is complete. Non-being in the form of the threat of loss of self in the group has not yet appeared' (ibid., p. 95).

11 ibid., pp. 94-95: 'There is no collective anxiety save an anxiety which has overtaken many or all members of a group and has been intensified or changed by becoming universal. The same is true of what is wrongly called collective courage. There is no entity "we-self" as the subject of courage. There are selves who participate in a group and whose character is partly determined by this participation. The assumed we-self is a common quality of ego-selves within a group. The courage to be as part is like all forms of courage, a quality of individual selves.' 
as a means of affirmation, it holds at bay the structures of destruction by which it is threatened both from within and from beyond.

By the expression courage to be as oneself Tillich means the kind of courage whereby, anxious in respect of the problematics of historical selfhood, the individual seeks to address this anxiety by way, not now of social, institutional or ideological alignment, but of an encounter with self in the depths. Sensitive to the forces at work within him making by turns for being and for non-being, and yet unwilling either by formation or by conviction, or both, to deliver himself to the collective solution, he looks instead to the interrogation of his own existence as a point of departure, the courage to be as oneself, therefore, taking the form of a seeking out of the deep rationality of self as glimpsed across its surface irrationality, across the clutter of high-level consciousness making in the ordinary way of things for distraction, confusion, and self-inexplicability. Tillich, with special reference at this point to the courage of the Enlightenment as, in this respect, exemplary, puts it thus:

Courage to be as oneself, as this is understood in the Enlightenment, is a courage in which individual self-affirmation includes participation in universal, rational, self-affirmation. Thus it is not the individual self as such which affirms itself but the individual self as the bearer of reason. The courage to be as oneself is the courage to follow reason and to defy irrational authority. In this respect but only in this respect - it is neo-Stoicism. For the courage to be of the Enlightenment is not a resigned courage to be. It dares not only to face the vicissitudes of fate and the inescapability of death but to affirm itself as transforming reality according to the demands of reason. It is a fighting, daring courage. It conquers the threat of meaninglessness by courageous action. It conquers the threat of guilt by accepting errors, shortcomings, misdeeds in the individual as well as in social life as unavoidable and at the same time to be overcome by education. The courage to be as oneself within the atmosphere of Enlightenment is the courage to affirm oneself as a bridge from a lower to a higher state of rationality. ${ }^{12}$

Courage as the courage to be as oneself, therefore, is the courage of being in the structured character of being, herein lying its power to overcome the threat of non-being as its demonic counterpart. Now neither of these forms of courage, Tillich thinks, excludes the other, the courage to be as part everywhere bearing deep within itself something of the courage to be as oneself and the courage to be as oneself everywhere shading off into the 
courage to be as part, into the courage of belonging. Nonetheless, as a way of setting up the issue here - namely the interaction of anxiety and courage as paradigms of consciousness - the distinction may be allowed to stand. Both ontologically, in respect of its basic taxonomy, and historically, in respect of its basic phenomenology, it takes us to the heart of the matter.

3. Typically, Tillich thinks, ${ }^{13}$ the courage of the Middle Ages was the courage to be as part, the courage to affirm self by way of the great powerconfigurations presiding over human affairs in this period and having about them both a prior and a providential status, a situation which Dante, with his sense of the city, empire and Church - of civitas, imperium, and ecclesia - as part of the pre-ordained pattern of things, reflects perfectly. First, then, comes the city, which, in addition to its function as a means of survival (no one man being equal to the practicalities of his existence), constitutes both a context and a co-efficient of historical selfhood, both the whereabouts and the means of a properly fulfilled humanity; on the one hand, then, and in respect first of all of survival pure and simple, this passage from the Convivio at IV.iv.2: 'E sì come un uomo a sua sufficienza richiede compagnia dimestica di famiglia, così una casa a sua sufficienza richiede una vicinanza: altrimenti molti difetti sosterrebbe che sarebbero impedimento di felicitade. E però che una vicinanza [a] sé non può in tutto satisfare, conviene a satisfacimento di quella essere la cittade, ${ }^{14}$ while on the other, and as touching now on the idea of the city as the crucible of properly human being and becoming as determined in this or that individual by way of personality and/or vocation, these lines (115-48) from Paradiso VIII:

13 ibid., pp. 96-97: 'The courage of the Middle Ages [...] is basically the courage to be as a part. The so-called realistic philosophy of the Middle Ages is a philosophy of participation. It presupposes that universals logically and collectives actually have more reality than the individual. The particular (literally: being a small part) has its power of being by participation in the universal. The self-affirmation expressed, for instance, in the self-respect of the individual is self-affirmation as follower of a feudal lord, or as the member of a guild, or as the student in an academic corporation, or as a bearer of a special function like that of a craft or a trade or a profession. But the Middle Ages, in spite of all primitive elements, is not primitive. Two things happened in the ancient world which separate medieval collectivism definitely from primitive collectivism. One of these was the discovery of personal guilt called by the prophets guilt before God: the decisive step to the personalization of religion and culture. The other was the beginning of autonomous question-asking in Greek philosophy, the decisive step to the problematization of culture and religion. Both elements were transmitted to the medieval nations by the Church. With them went the anxiety of guilt and condemnation and the anxiety of doubt and meaninglessness.'

${ }^{14}$ And just as the individual for his fulfilment requires the domestic society of a family, so the household requires for its fulfilment to be part of a neighbourhood; it would otherwise be lacking in many ways, and thus be precluded from attaining happiness. Again, a single neighbourhood cannot satisfy all its own needs; for this the city is required. 
Ond' elli ancora: "Or dì: sarebbe il peggio

per l'omo in terra, se non fosse cive?".

"Sì", rispuos' io; "e qui ragion non cheggio".

"E puot' elli esser, se giù non si vive diversamente per diversi offici?

Non, se 'l maestro vostro ben vi scrive".

Sì venne deducendo infino a quici;

poscia conchiuse: "Dunque esser diverse

convien di vostri effetti le radici:

per ch'un nasce Solone e altro Serse,

altro Melchisedèch e altro quello

che, volando per l'aere, il figlio perse.

La circular natura, ch'è suggello

a la cera mortal, fa ben sua arte, ma non distingue l'un da l'altro ostello.

Quinci addivien ch'Esaù si diparte per seme da Iacòb; e vien Quirino a sì vil padre, che si rende a Marte.

Natura generata il suo cammino simil farebbe sempre a' generanti, se non vincesse il proveder divino.

Or quel che t'era dietro t'è davanti: ma perché sappi che di te mi giova, un corollario voglio che t'ammanti.

Sempre natura, se fortuna trova discorde a sé, com' ogne altra semente fuor di sua regïon, fa mala prova.

$\mathrm{E}$ se 'l mondo là giù ponesse mente al fondamento che natura pone, seguendo lui, avria buona la gente.

Ma voi torcete a la religïone tal che fia nato a cignersi la spada, e fate re di tal ch'è da sermone;

onde la traccia vostra è fuor di strada". ${ }^{15}$

15 "Now say, would it be worse for man on earth if he were not a citizen?" "Yes", I replied, "and here I ask for no proof". "And can that be, unless men below live in diverse ways for diverse duties? Not if your master writes well of this for you." Thus he came deducing as far as here, then he concluded, "therefore the roots of your work must needs be diverse, so that one is born Solon and another Xerxes, one Melchizedeck and another he who flew through the air and lost his son. Circling nature, which is a seal on the mortal wax performs its art well, but does not distinguish one house from another. Whence it happens that Esau differs in seed from Jacob, and Quirinus comes from so base a father that he is ascribed to Mars. The begotten nature would always make its course like its begetters, did not divine provision overrule. Now that which was behind you is before you; but that you may know 
It is then, by way of the special socio-political and cultural complexion of the city that the individual sees and lays hold of the moral and ontological possibilities properly his and his alone, of all that he has it in himself to be and to become, at which point courage as the courage to be as part - the courage, that is to say, of affirmation as a matter of allegiance - moves into view.

But that is not all, for no less indispensable to a consummate act of specifically human being is the empire as the ground and guarantee of universal peace. ${ }^{16}$ The idea is simple. Man as man, Dante maintains in the Monarchia, has a collective as well as a private end, the collective end

that I delight in you, I will have a corollary cloak you round. Ever does nature, if she find fortune discordant with herself, like any kind of seed out of its proper region, come to ill result. And if the world below would give heed to the foundation which nature lays, and followed it, it would have its people good. But you wrest to religion one born to gird on the sword, and you make a king of one that is fit for sermons; so that your track is off the road". Aristotle, Pol. I.2; 1252b27-29 ('Quae autem ex pluribus vicis communitas perfects civitas, iam omnis, habens terminum per se sufficientiae'), etc., though see in relation to Dante and Aristotle, A. H. Gilbert, 'Had Dante read the Politics of Aristotle', Publications of the Modern Language Association 43 (1928), 3, 602-13; L. Minio Paluello, 'Dante's Reading of Aristotle', in The World of Dante. Essays on Dante and his Times, ed. C. Grayson (Oxford: Clarendon Press, 1980), pp. 61-80, subsequently in Lugghicruciali in Dante, ed. F. Santi (Spoleto: Centro Italiano di Studi sull'Alto Medioevo, 1993), pp. 29-49, and in Dante. The Critical Complex, 8 vols, ed. R. Lansing (New York and London: Routledge, 2003), vol. 3, pp. 35-54. On Dante and the city, E. Peters, 'Pars, parte: Dante and an Urban Contribution to Political Thought', in H. A. Miskimin et al. (eds), The Medieval City (New Haven: Yale University Press, 1977), pp. 113-40; C. Honess, 'Feminine Virtues and Florentine Vices: Citizenship and Morality in Paradiso XV-XVII', in J. R. Woodhouse (ed.), Dante and Governance (Oxford: Clarendon Press, 1997), pp. 102-20; C. Keen, Dante and the City (Stroud: Tempus, 2003). More generally, G. Holmes, 'The Emergence of an Urban Ideology at Florence, c. 1250-1450', Transactions of the Royal Historical Society 22 (1973), 111-34; J. K. Hyde, Society and Politics in Medieval Italy. The Evolution of Civil Life, 1000-1350 (New York and London: St Martin's Press, 1973); D. Waley, The Italian City-Republics, 3rd edn (London: Longman, 1988); P. Jones, The Italian City State. From Comune to Signoria (Oxford: Clarendon Press, 1997).

${ }^{16}$ Preliminary in respect of an ample bibliography, F. Ercole, Il pensiero politico di Dante, 2 vols (Milan: Alpes, 1927-28); F. Battaglia, Impero, Chiesa e Stati particolari nel pensiero di Dante (Bologna: Zanichelli, 1944); A. P. D'Entrèves, Dante as a Political Thinker (Oxford: Clarendon Press, 1952; repr. 1965); M. Barbi, 'L'ideale politico-religioso di Dante', 'L'Italia nell'ideale politico di Dante' and 'Impero e Chiesa', in Problemi fondamentali per un nuovo commento alla Divina Commedia (Florence: Sansoni, 1955), pp. 49-68, 69-89, 91-114; C. T. Davis, Dante and the Idea of Rome (Oxford: Clarendon Press, 1957); idem, Dante's Italy and Other Essays (Philadelphia: University of Pennsylvania Press, 1984); B. Nardi, 'Il concetto dell'Impero nello svolgimento del pensiero dantesco' and 'Tre pretese fasi del pensiero politico di Dante', in Saggi di filosofia dantesca, 2nd edn (Florence: La Nuova Italia, 1967), pp. 215-75 and 276-310; M. Maccarrone, 'Papato e Impero nella Monarchia', Nuove letture Jantesche 8 (1976), 259-332; D. Mancusi-Ungaro, Dante and the Empire (New York: Peter Lang, 1987); J. R. Woodhouse (ed.), Dante and Governance (previous note). 
consisting in the actualization at any given moment of his total capacity for knowing and understanding. But actualization on any scale and with any degree of permanence requires a quiet mind and an untroubled spirit, which is where the emperor comes in, he and he alone being in a position to establish and maintain the peace and quiet necessary to the joint enterprise; on the notion, then, of collective intelligence and of universal peace as its prior and subsistent condition, these lines from not too far into the first book of the Monarchia:

Satis igitur declaratum est quod proprium opus humani generis totaliter accepti est actuare semper totam potentiam intellectus possibilis, per prius ad speculandum et secondario propter hoc ad operandum per suam extensionem. Et quia quemadmodum est in parte sic est in toto, et in homine particulari contingit quod sedendo et quiescendo prudentia et sapientia ipse perficitur, patet quod genus humanum in quiete sive tranquillitate pacis ad proprium suum opus ... liberrime atque facillime se habet. Unde manifestum est quod pax universalis est optimum eorum que ad nostram beatitudinem ordinantur.

(Mon. I.iv.1-2) $)^{17}$

while on the notion of peace and quiet thus understood as the responsibility

17 Now it has been sufficiently explained that the activity proper to mankind considered as a whole is constantly to actualize the full intellectual potential of humanity, primarily through thought and secondarily through action (as a function and extension of thought). And since what holds true for the part is true for the whole, and an individual human being "grows perfect in judgment and wisdom when he sits at rest", it is apparent that mankind most freely and readily attends to this activity ... in the calm or tranquillity of peace. Hence it is clear that universal peace is the best of those things which are ordained for our human happiness. On the collective actualization of the possible intellect, Mon. I.iii 7-8: 'Patet igitur quod ultimum de potentia ipsius humanitatis est potentia sive virtus intellectiva. Et quia potentia ista per unum hominem seu per aliquam particularium comunitatum superius distinctarum tota simul in actum reduci non potest, necesse est multitudinem esse in humano genere, per quam quidem tota potentia hec actuetur; sicut necesse est multitudinem rerum generabilium ut potentia tota materie prime semper sub actu sit; aliter esset dare potentiam separatam, quod est inpossibile.' For the 'sedendo et quiescendo prudentia et sapientia ipse perficitur' motif, Aristotle, Physics VII, 3; $247 \mathrm{bl}$ 18; Thomas, $S c G$ III.xxxvii.7: 'Ad hanc etiam omnes aliae humanae operationes ordinari videntur sicut ad finem. Ad perfectionem enim contemplationis requiritur incolumitas corporis, ad quam ordinantur artificialia omnia quae sunt necessaria ad vitam. Requiritur etiam quies a perturbationibus passionum, ad quam pervenitur per virtutes morales et per prudentiam; et quies ab exterioribus perturbationibus, ad quam ordinatur totum regimen vitae civilis'; In Eth. X.vii, lect. xi, n. 4 ult.: 'Haec est enim felicitas speculativa, ad quam tota vita politica videtur ordinata; dum per pacem, quae per ordinationem vitae politicae statuitur et conservatur, datur hominibus facultas contemplandi veritatem.' 
of the emperor, this passage from the third book:

Et cum ad hunc portum vel nulli vel pauci, et hii cum difficultate nimia, pervenire possint, nisi sedatis fluctibus blande cupiditatis genus humanum liberum in pacis tranquillitate quiescat, hoc est illud signum ad quod maxime debet intendere curator orbis, qui dicitur romanus Princeps, ut scilicet in areola ista mortalium libere cum pace vivatur.

(Mon. III.xvi.11) $)^{18}$

Now imperial jurisdiction, as Dante understands it, is not a moral jurisdiction. On the contrary, imperial writ runs fully and unequivocally only in matters of pure positive law, in all other cases wherever human law preserves by virtue of its descent from the natural law a moral component - the subject retaining a right of dissent. ${ }^{19}$ In the degree, however, to which a man 'grows wise by sitting at rest', imperial power is present to him as a necessary condition of his proper

18 And since none can reach this harbour (or few, and these few with great difficulty) unless the waves of seductive greed are calmed and the human race rests free in the tranquillity of peace, this is the goal which the protector of the world, who is called the Roman Prince, must strive with all his might to bring about: i.e. that life on this threshing-floor of mortals may be lived freely and in peace. On the further and more refined notion of the emperor as emancipator of the spirit, as guaranteeing by way of his universal jurisdiction a free passage in the subject from seeing and understanding to willing and doing, I.xii.3-4 and 9: 'Et ideo dico quod iudicium medium est apprehensionis et appetitus: nam primo res apprehenditur, deinde apprehensa bona vel mala iudicatur, et ultimo iudicans prosequitur sive fugit. Si ergo iudicium moveat omnino appetitum et nullo modo preveniatur ab eo, liberum est; si vero ab appetitu quocunque modo proveniente iudicium moveatur, liberum esse non potest, quia non a se, sed ab alio captivum trahitur [...] Genus humanum solum imperante Monarcha sui et non alterius gratia est: tunc enim solum politie diriguntur oblique - democratie scilicet, oligarchie atque tyrampnides - que in servitutem cogunt genus humanum, ut patet discurrenti per omnes, et politizant reges, aristocratici quos optimates vocant, et populi libertatis zelatores; quia cum Monarcha maxime diligat homines, ut iam tactum est, vult omnes homines bonos fieri: quod esse non potest apud oblique politizantes.'

${ }^{19}$ Conv. IV.ix.14-15: 'Queste cose simigliantemente, che de l'altre arti sono ragionate, vedere si possono ne l'arte imperiale; ché regole sono in quella che sono pure arti, sì come sono le leggi de' matrimonii, de li servi, de le milizie, de li successori in dignitade, e di queste in tutto siamo a lo Imperadore subietti, sanza dubbio e sospetto alcuno. Altre leggi sono che sono quasi seguitatrici di natura, sì come constituire l'uomo d'etade sofficiente a ministrare, e di queste non semo in tutto subietti. Altre molte sono, che paiono avere alcuna parentela con l'arte imperiale - e qui fu ingannato ed è chi crede che la sentenza imperiale sia in questa parte autentica -: sì come [diffinire] giovinezza e gentilezza, sovra le quali nullo imperiale giudicio è da consentire, in quanto elli è imperadore: però, quello che è di Dio sia renduto a Dio.' J. Took, “'Diligite iustitiam qui iudicatis terram”: Justice and the Just Ruler in Dante', in Dante and Governance, ed. J. R. Woodhouse (note15 above), pp. 137-51. 
emergence, at which point courage as the courage to be as part once again moves centre stage.

Finally, there is the Church, the gathered community of souls naming the name here below on earth and in heaven. ${ }^{20}$ Now here there is a paradox, for not only was Dante among the staunchest critics of the Church in its lovelessnesss, ${ }^{21}$ but he spent a great deal of time and energy rescuing the human project from what amounts to the clerical world-view, to a finality impatient of qualitative and thus of political distinctions along the way. In the Convivio, this declericalization of the moral and intellectual life takes the form of an attempt to identify a species of human happiness appropriate to, and realizable by, those 'many men and women in this language of ours ... bowed down by domestic and civic care'. ${ }^{22}$ In the Monarchia it

20 P. Brezzi, 'Dante e la Chiesa del suo tempo', in Dante e Roma: atti del convegno di studi, Roma 8-9-10 aprile, 1965 (Florence: Le Monnier, 1965), pp. 97-113 (with, at pp. 115-35, R. Manselli, 'Dante e l'ecclesia spiritualis'); idem, 'L'Italia tra Chiesa e Impero nell'età di Dante', in Letture classensi 16 (1987), pp. 99-118; P. Armour, The Door of Purgatory. A Study of Multiple Symbolism in Dante's Purgatorio (Oxford: Clarendon Press, 1983); S. Botterill, 'Not of This World: Spiritual and Temporal Powers in Dante and Bernard of Clairvaux', Lectura Dantis 10 (1992), 8-21; idem, 'Ideals of the Institutional Church in Dante and Bernard of Clairvaux', Italica 78 (2001), 3, 297-313 (subsequently in Dante: The Critical Complex, 8 vols, ed. R. Lansing (New York and London: Routledge, 2003), vol. 4, pp. 405-21); A. K. Cassell, “'Luna est Ecclesia”: Dante and the “Two Great Lights”,' Dante Studies 119 (2001), 1-26; C. T. Davis, 'Dante and Ecclesiastical Property', in Dante: The Critical Complex (above), vol. 5, pp. 294-307 (originally in Law in Mediaeval Life and Thought, ed. E. B. King and S. J. Ridyard (Sewanee, Tenn.: The Press of University of the South, 1990), pp. 244-57); M. S. Kempshall, 'Accidental Perfection:Ecclesiology and Political Thought in Monarchia', in P. Acquaviva and J. Petrie (eds), Dante and the Church: Literary and Historical Esdays (Dublin: Four Courts Press, 2007), pp. 127-71 (also, in the same volume, pp. 93-125, P. Nasti, 'The Amorous Bride and her Lovers: Images of the Church in the Heaven of the Sun').

${ }^{21}$ Recently on the forms of Dantean dissent, A. Consoli, 'Dante anticlericale?', in Dante ecumenico. Letture e postille (Naples: Conte, 1973), pp. 20-24; A. Comollo, Il dissenso religioso in Dante (Florence: Olschki, 1990; Biblioteca dell'Archivum Romanicum', 1st series, vol. 235); V. Esposito, La 'Commedia' Jantesca tre fede e dissenso (Pescara: Tracce, 1999). The notion of Dantean dissent stands, however, to be developed in terms of what Tillich calls the protestant principle (as distinct from Protestantiom as but the most dramatic of its historical manifestations) everywhere at work in Christian spirituality as the guardian and guarantor of its deep substance, as that whereby the religious undertaking is protected against 'the aspiration of its own religious and secular appearances' (Theology of Culture, ed. R. C. Kimball (London, Oxford and New York: Oxford University Press, 1959), p. 29). For an account of Dante's restiveness as a specifically Christian thinker in terms (a) of his sense of the cultural encounter in general as distinct from the ecclesiastical encounter in particular as salvifically significant, and $(b)$ of his commitment to the notion of episcopacy as a matter ultimately of self-episcopacy or self-oversight (this being the final cause every proper striving of the spirit in man), see pp. 155-70 above ('Dante and the Protestant Principle').

${ }^{22}$ Conv. I ix.5 and I.i.4. 
takes the form of a distinction between, as Dante sees it, the two kinds of happiness proper to man as man, namely the happiness of the next life overseen by the pope as bridge-builder-in-chief (pontifex maximus) on the basis of revelation, and the happiness of this life overseen by the emperor, as assisted by the philosopher, on the basis of reason, ${ }^{23}$ this, then, being his way of loosening the kind of theologism and ecclesiasticism whereby the Church is able to insist on its primacy in every area of the moral and political life. Here again, however, we must be careful, for not only does declericalization not mean detheologization, but the ferocity of his denunciation of the Church in its lovelessness is itself testimony to the strength of his commitment to the status of the Church as but the continuing presence of Christ to us, albeit of the Christ crucified afresh. To be beyond the pale of the Church, then, and of the faith she proclaims is to be cast adrift on the sea of directionlessness and of despair, at which point courage as the courage to be as part yet again commends itself as a principle of self-understanding and self-implementation.

4. For Dante too, then, the formal structures of being and becoming civitas, imperium and ecclesia - matter, each having a part to play in the coming about of man as man; for it is by way of the city and of the unique dynamic of the city that the individual comes home to himself as a soldier or sermonizer, by way of the empire that he enjoys the peace and quiet necessary to both the collective and the individual undertaking, and by way of the Church that he knows himself even now as party to the elect. To this extent, therefore, Dante fits the bill, his too being a sense of courage as the courage to be as part. ${ }^{24}$ But to live with the Commedia as an account of the soul's journey into God as verified at first hand by the one who says 'I' is straightaway to become aware of its character as an essay in courage, not, in fact, as the courage to be as part, but as the courage to be as oneself, in the kind of courage whereby the individual called from

${ }^{23}$ Mon. III.xvi.7-8: 'Duos igitur fines providentia illa inenarrabilis homini proposuit intendendos: beatitudinem scilicet huius vite, que in operatione proprie virtutis consistit et per terrestrem paradisum figuratur; et beatitudinem vite ecterne, que consistit in fruitione divini aspectus ad quam propria virtus ascendere non potest, nisi lumine divino adiuta, que per paradisum celestem intelligi datur. Ad has quidem beatitudines, velut ad diversas conclusiones, per diversa media venire oportet. Nam ad primam per phylosophica documenta venimus, dummodo illa sequamur secundum virtutes morales et intellectuales operando; ad secundam vero per documenta spiritualia que humanam rationem transcendunt, dummodo illa sequamur secundum virtutes theologicas operando, fidem spem scilicet et karitatem.'

${ }^{24}$ W. Kölmel, 'Chiesa, cristianità, genero umano: riflessioni sull'autocomprensione della società medievale', Cristianesimo nella Storia. Ricerche storiche, esegetiche, teologiche 5 (1984), 3, 507-22. 
beforehand to be in God as the first and final cause of his every aspiration of the spirit seeks to lay hold of his proper humanity from out of that humanity, from out of the power properly his to moral and ontological determination. Indispensable, then, as city, empire and Church are as principles both of self-recognition and of self-affirmation, there can be no escaping the anxiety of existence by taking refuge in the structures of collectivity as a response to the sensation of dividedness and catastrophe; for neither the structures of local or of world citizenship (civitas, imperium) nor the communion of the faithful as those called out for God's service (ecclesia) can exempt the individual from the struggle to be by way of an act of self-knowledge, of self-reconfiguration and of self-transcendence as the condition of moral and ontological emergence, at which point we witness the triumph of the courage to be as oneself over the courage to be as part as a way of seeing and understanding the human predicament. Short, in other words, of courage as the courage to be as oneself, as the courage to engage with self from out of the power of self to self-determination, there can be no question of homecoming, for short of courage thus understood the individual is forever engaged in a process of evasion, of sidestepping what actually matters about his presence in the world as a creature of accountability.

The moral component in this situation is set out by Dante in the central cantos of the Purgatorio, cantos turning on a sense of the human project as a matter of affective organization. Man as man, then, knows himself in a twofold order of loving. He knows himself by way $(a)$ of the kind of love given with the act itself of existence, of an 'amore naturale' predating the moral moment proper of human experience and thus governing it, and (b) of the kind of love generated by this or that passing object of perception, of an 'amore d'animo' or contingent loving post-dating the moral moment and thus governed by it. His proper task, therefore, when it comes to right loving, lies not so much in the denial of this or that set or sub-set of loveimpulses, as in their co-ordination, in the bringing home of elective to essential loving such that each alike serves the highest good, the call to be in, through and for God as the alpha and omega of all being. This is the meaning of the 'Né creator né creatura' passage beginning at Purg. XVII.91, a passage placed by Dante upon the lips of Virgil but, especially as it goes on, transparent to its theological content, to the possibility of love as, withal, a principle of apostasy (the 'contra 'l fattore adovra sua fattura' moment of the last line):

"Né creator né creatura mai", cominciò el, "figliuol, fu sanza amore, o naturale o d'animo; e tu 'l sai. 
Lo naturale è sempre sanza errore, ma l'altro puote errar per malo obietto o per troppo o per poco di vigore.

Mentre ch'elli è nel primo ben diretto, e ne' secondi sé stesso misura, esser non può cagion di mal diletto;

ma quando al mal si torce, o con più cura

o con men che non dee corre nel bene, contra 'l fattore adovra sua fattura". ${ }^{25}$

Now in the degree to which the individual seeks to measure secondary loving up against primary loving (the 'ne' secondi sé stesso misura' of line 98) he knows himself in the consummate character of his existence as a creature in potential to God. In the degree, by contrast, to which, waylaid by proximate possibility, he falls short in this, he knows himself only in the kinds of fear, disorientation and self-inexplicability characteristic of being in its remotion. This, then, is where Dante begins. He begins with the phenomenology of dividedness, with the psychological substance of being as ranged over against itself in the forum of conscience:

Nel mezzo del cammin di nostra vita mi ritrovai per una selva oscura, ché la diritta via era smarrita.

Ahi quanto a dir qual era è cosa dura esta selva selvaggia e aspra e forte che nel pensier rinova la paura! ...

Io non so ben ridir com' i' v'intrai, tant' era pien di sonno a quel punto che la verace via abbandonai ...

questa mi porse tanto di gravezza con la paura ch'uscìa di sua vista, ch'io perdei la speranza dell'altezza.

(Inf. I.1-6, 10-12, 52-54) $)^{26}$

${ }^{25}$ He began: "Neither Creator nor creature, my son, was ever without love, either natural or of the mind, and this you know. The natural is always without error; but the other may err either through an evil object, or through too much or too little vigour. While it is directed on the primal good, and on secondary goods observes right measure, it cannot be the cause of sinful pleasure. But when it is turned awry to evil, or speeds to good with more zeal, or with less, than it ought, against the Creator works his creature."

${ }^{26}$ Midway in the journey of our life I found myself in a dark wood, for the straight way was lost. Ah, how hard it is to tell how that wood was, wild, rugged, harsh; the very thought of it renews my fear ... I cannot rightly say how I entered it, I was so full of sleep at the moment I left the true way ... she put such heaviness upon me with the fear that came from the sight of her that I lost hope of the height. 
And it is into this situation that courage as the courage to be as oneself enters as that whereby the individual embarks on the way of death and resurrection. First, then, and as sustained by a movement of grace tending from deep within it to confirm and strengthen it, comes the courage of acknowledgement, the courage whereby, sensitive to everything within the economy of personality making for the alternative solution, the individual commits himself to the way of descent and of disclosure, to a laying open of self in the demonic substance of self; hence, on the threshold of the text, the 'Quali fioretti dal notturno gelo' passage of Inf. II.121-42, superlative in its account of courage as the courage of commitment, as that whereby, secure in its sense of the providentiality of it all, of the journey as authorized from on high, the pilgrim spirit sets about the business of recognition, of contemplating as the condition of all righteousness in human experience the spectacle of unrighteousness:

"Dunque: che è? perché, perché restai, perché tanta viltà nel core allette, perché ardire e franchezza non hai,

poscia che tai tre donne benedette curan di te ne la corte del cielo, e 'l mio parlar tanto ben ti promette?".

Quali fioretti dal notturno gelo chinati e chiusi, poi che 'l sol li 'mbianca, si drizzan tutti aperti in loro stelo,

tal mi fec' io di mia virtude stanca, e tanto buono ardire al cor mi corse, ch'i' cominciai come persona franca:

"Oh pietosa colei che mi soccorse! e te cortese ch'ubidisti tosto a le vere parole che ti porse!

Tu m'hai con disiderio il cor disposto sì al venir con le parole tue, ch'i' son tornato nel primo proposto.

Or va, ch'un sol volere è d'ambedue: tu duca, tu segnore e tu maestro". Così li dissi; e poi che mosso fue, intrai per lo cammino alto e silvestro. ${ }^{27}$

\footnotetext{
27 "What, then, is this? Why, why do you hold back? Why do you harbour such cowardice in your heart? Why are you not bold and free, when in Heaven's court three such blessed ladies are mindful of you, and my words pledge you so great a good?" As little flowers, bent down and closed by chill of night, straighten and all unfold upon their stems when the sun brightens them, such in my faint strength did I become; and so much good courage rushed to my heart that I began, as one set free, "Oh, how compassionate
} 
But that is not all, for following hard upon the heels of courage as the courage of acknowledgement comes the courage of alignment, the courage whereby, having seen and contemplated self in its destitution, but having by grace taken the guilt of this situation into itself, the soul begins now to contemplate the shape and substance of its loving, the pattern of its disorganized affectivity - the business of the purgatorial phase of its journey into God. First, then, comes the anti-purgatorial moment of the journey, the moment of spiritual readying giving way at last to the travail of the purgatorial moment proper, to the nothing if not painful fashioning from the disgregated substance of being so far something more intimately ordered, more properly transparent to the deep reasons of that being. With this, the spirit comes at last into the fullness of its proper humanity, to a now uncluttered opening out of the intentional upon the actual and a fresh equality of self to an act both of self-understanding and of world-historical understanding, each of these things, however, bereft of its power to despair and destruction. Here too, then, it is a question of courage, of the courage, not now of recognition, but of reconfiguration, of affirming self in the revised structure of self.

But even that is not all, for the courage of acknowledgement and the courage of alignment flow into the courage of actualization, into the courage required of the individual as, risking all for the sake of finding all, he maps his humanity onto the kind 'transhumanity' present to him as but the most immanent of his immanent possibilities; so, then, as a call to attention in respect of this, the final step along the way, these lines from Canto II of the Paradiso, an essay in the courage of anticipation, the courage required of the pilgrim spirit as it projects itself upon its ultimate possibility:

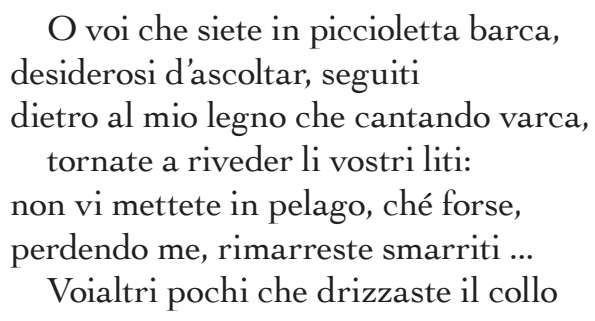

was she who helped me, and how courteous were you, so quick to obey the true words she spoke to you! By your words you have made me so eager to come with you that I have returned to my first resolve. Now on, for a single will is in us both; you are my leader, you are my master and my teacher". So I said to him, and when he moved on, I entered along the deep and savage way. See too in respect of the Inferno as, whatever else it is, an essay in the rhythm of ontological courage the "Or sie forte e ardito. Omai si scende per sì fatte scale' moment of Inf. XVII.81-82 and the "Ecco Dite", dicendo, "ed ecco il loco / ove convien che di fortezza t'armi' moment of XXXIV. 20-21. 
per tempo al pan de li angeli, del quale vivesi qui ma non sen vien satollo, metter potete ben per l'alto sale vostro navigio, servando mio solco dinanzi a l'acqua che ritorna equale.

$(\text { Par. II.1-6, 10-15) })^{28}$

while as registering the triumph of the individual as he comes into the presence of the One who is as of the essence, these lines from Canto XXXIII of the Paradiso, an essay now in the courage of accomplishment, the courage of the pilgrim spirit as it rejoices at last in a consummate act of understanding:

E' mi ricorda ch'io fui pió ardito per questo a sostener, tanto ch'i' giunsi l'aspetto mio col valore infinito.

Oh abbondante grazia ond' io presunsi

ficcar lo viso per la luce etterna, tanto che la veduta vi consunsi!

Nel suo profondo vidi che s’interna, legato con amore in un volume, ciï che per l'universo si squaderna:

sustanze e accidenti e lor costume quasi conflati insieme, per tal modo che ciï ch'i' dico ä un semplice lume.

La forma universal di questo nodo credo ch 'i' vidi, perchÇ pió di largo, dicendo questo, mi sento ch'i' godo.

(Par. XXXIII.79-93) ${ }^{29}$

${ }^{28}$ O you that are in your little bark, eager to hear, following behind my ship that singing makes her way, turn back to see again your shores. Do not commit yourselves to the open sea, for perchance, if you lost me, you would remain astray ... You other few who lifted up your necks betimes for bread of angels, on which men here subsist but never become sated of it, you may indeed commit your vessel to the deep brine, holding to my furrow ahead of the water that turns smooth again.

${ }^{29}$ I remember that on this account I was the bolder to sustain it, until I united my gaze with the infinite goodness. Oh abounding grace whereby I presumed to fix my look through the eternal light so far that all my sight was spent therein. In its depth I saw ingathered, bound by love in one single volume, that which is dispersed in leaves throughout the universe: substances and accidents and their relations, as though fused together in such a way that what I tell is but a simple light. The universal form of this knot I believe that I saw, because, in telling this, I feel my joy increase. 
To embark on the way of transhumanity, Dante suggests, is to embark on the way, not merely of recognition and of reconfiguration (each alike preliminary in respect of what comes next), but of a positive redefining of self on the planes both of knowing and of loving, of a re-dimensioning of cognitive and affective selfhood. With this, then, with what amounts to a hymn to courage as the virtue par excellence of being in its 'outstandingness' (ex-sistere), we are in a position both to commend and to qualify Tillich's account of courage at least as far as Dante is concerned; for if on the one hand Dante's is indeed a commitment to the notion of courage as the courage to be as part, civitas, imperium and ecclesia entering properly into the soteriological scheme, courage thus understood stands even so to be taken up as far as the Commedia is concerned in the courage to be as oneself, in the kind of courage born not of allegiance, but of actuality, of knowing self in the thereness of self.

5. Put thus, Dante's, for all his commitment in the Commedia to the notion of grace as the ground and guarantee of every significant inflexion of the spirit in man, is nonetheless a heroic spirituality, heroic in its commitment to courage under both kinds - but above all as the courage to be as oneself as the prius of everything that ultimately matters in human experience, of every reaching out of the creature towards the creator. But there is more, for the courage he commends as a disposition of the spirit in its seeking out of God as the beginning and end of all seeking in human experience is the courage he himself lived out as poet and prophet of the pilgrim way. Deriving, in other words, comfort and encouragement from all those of his auctores to whom he was most indebted and of whom he was most enamoured (from Thomas, Albert, Bonaventure, Bernard, Boethius and from the cloud of witnesses among whom he himself now numbers), he nonetheless fashioned a theology quite other than anything he discovered in his texts; for his, wedded as it was to the idea pure and simple in all the exquisite purity of the idea, was an exploration of the theological issue by way not, in fact, of the idea tout court, but of the drama of being and becoming as lived out at first hand by the one who says 'I'. Responsive in the highest degree to the contents of dogmatic awareness, his was an account of the religious situation by way of its inner agony, of the pain of knowing self in the inexplicability of self and of this as the condition of new life. The courage to be, therefore, fully thematicized in the text and commended there as an object of contemplation, at every point transcends its merely textual elaboration to subsist as its encompassing - an instance, we might say, of metalettarietà at its most sublime. 